\title{
Omnivory and opportunism characterize food webs in a large dry-tropics river system
}

\author{
Melanie L. Blanchette ${ }^{1,2,5}$, Aaron M. Davis ${ }^{3,6}$, Timothy D. Jardine $e^{4,7}$, and Richard G. Pearson ${ }^{1,3,8}$ \\ ${ }^{1}$ School of Marine and Tropical Biology, James Cook University, Townsville, Queensland 4811, Australia \\ ${ }^{2}$ Mine Water and Environment Research Centre (MiWER), Edith Cowan University, Joondalup, Western Australia 6027, Australia \\ ${ }^{3}$ Centre for Tropical Water and Aquatic Ecosystem Research (TropWater), James Cook University, Townsville, Queensland 4811, \\ Australia \\ ${ }^{4}$ Australian Rivers Institute, Griffith University, Nathan, Queensland 4111, Australia
}

\begin{abstract}
We analyzed basal sources, trophic levels, and connectance in dry-season food webs on 4 rivers in the upper Burdekin catchment in the dry tropics of northeastern Australia. The region is characterized by episodic summer rainfall, and most of the annual river flow occurs in a short period. In the dry season, rivers typically contract into a series of water holes of varying permanence and hydrologic connectivity. We used stable-isotope and stomach-content analyses to identify trophic levels of macroinvertebrates and fish, and we used a mixing model (SIAR) to identify foodweb basal sources at each site. We found substantial variability among sites in basal-source contributions, trophic position of individual taxa, and foodweb structure, and sites from the same river often were as different as sites from different rivers. Important basal sources at different sites included allochthonous tree litter, autochthonous algae and macrophytes, and Fe-fixing bacteria. Many relationships between consumers and basal sources were not resolved in the mixing model, mainly because of extensive omnivory or isotopic overlap among sources. Nevertheless, our results show high variability of dry-tropics river communities that extends beyond previously described macroinvertebrate assemblages to the broader food web. However, the main components of the upper trophic levels were similar across sites, such that different lower trophic levels supported similar assemblages of top consumers. These tropical rivers were defined by omnivory and ecological opportunism, which may be adaptations to seasonal hydrological variability.
\end{abstract}

Key words: tropical rivers, food webs, omnivory, stable isotopes, macroinvertebrates, fish, connectance, Burdekin

Food webs in tropical rivers are characterized by widespread omnivory and tend to be short, diffuse, and highly interconnected (Winemiller 2004, Douglas et al. 2005, Pusey et al. 2010). For example, large predatory fish can occupy trophic positions similar to those of smaller fish (Layman et al. 2005a) and, even within the same species, significant size-related shifts in trophic position can occur (Werner and Gilliam 1984, Davis et al. 2011). This trophic flexibility can extend to the broader food web, with tropical fishes filling ecological roles that normally are occupied by aquatic insects in temperate rivers (Winemiller 2004). Recent research has advanced our understanding of how river ecosystems of the seasonal tropics function, but significant gaps in this knowledge still exist (Pettit et al. 2011, Warfe et al. 2013).

Identifying sources of organic matter is fundamental to understanding the dynamics of food webs (Finlay 2001). Various models of the $\mathrm{C}$ pathways in rivers have been pro- posed, each reflecting the type of river for which they were developed (e.g., Vannote et al. 1980, Junk et al. 1989, Thorp and Delong 1994, Thorp et al. 2006). Typically, allochthonous material is the main $\mathrm{C}$ source for food webs in small forested streams (e.g., Anderson and Sedell 1979, Benfield and Webster 1985, Cheshire et al. 2005), whereas in larger systems, autochthonous sources of $\mathrm{C}$ are major drivers of food webs, especially in rivers with seasonal warm-weather floods (Thorp et al. 2006). Even in rivers with large amounts of riparian-derived leaf litter, autochthonous production can still be the main source of $\mathrm{C}$ (McCutchan and Lewis 2002), possibly because of its palatability to metazoans (Thorp and Delong 2002). In Australian rivers of the arid zone and the seasonal (wet-dry) tropics, autochthonous production has been described as the dominant source of $C$ for benthic metabolism and food webs (Bunn et al. 2003, Douglas et al. 2005, Fellows et al. 2007, Jardine et al. 2013). However, recognition of the var- 
iability of food webs and basal-source contributions in these rivers is growing (Leigh et al. 2010). Allochthonous C derived from terrestrial or floodplain sources may be important in food webs of large wet-dry tropical rivers with variable hydrological regimes (Zeug and Winemiller 2008, Leigh et al. 2010, Hunt et al. 2012), with overall importance varying according to season and consumer taxa (Hunt et al. 2012).

Assessments of consumer diets and foodweb structure generally have been achieved via stomach-content analysis (SCA). However, this approach can be limited because it provides only a snapshot of trophic interactions (Hyslop 1980), and little information on the assimilation of ingested material (Parkyn et al. 2001). This limitation has led to the increasing use of stable-isotope analysis (SIA), which provides longer-term dietary information and allows quantification of prey assimilation by consumers (Vander Zanden et al. 1997, Post 2002). Despite its constraints, SCA has the advantage of providing the identity and size of food items, which cannot be detected from SIA (Layman et al. 2005b, Winemiller et al. 2007). Therefore, SCA and SIA are often used together to provide complementary estimates of trophic position (Mantel et al. 2004, Layman et al. 2005b, Winemiller et al. 2007, Davis et al. 2012a).

Blanchette and Pearson $(2012,2013)$ showed that biophysical variables and macroinvertebrate assemblages are highly spatially and temporally variable in 4 rivers of the Burdekin catchment in northeastern Australia, and that local factors were as important as the regional setting in determining assemblage composition and temporal trajectories in these seasonal river systems (cf. Warfe et al. 2013). Here we investigated food webs and their basal sources in the same 4 rivers during the late dry season, when habitats would be most stable in terms of hydrology and other biophysical variables (Blanchette and Pearson 2013). Riparian condition and associated in-stream habitat metrics (e.g., variation in canopy cover, benthic leaf-litter cover, bank overhanging vegetation) strongly influenced macroinvertebrate assemblages in rivers of the Burdekin catchment on a local scale, with biophysical variables and assemblages from sites within the same river often as different as those between rivers (Blanchette and Pearson 2012, 2013). Therefore, the presence or absence of allochthonous material was a major ecological driver, and its influence on macroinvertebrate assemblages varied across the catchment. We hypothesized that broad foodweb structure would be similarly variable within and among rivers, with the relative importance of allochthonous and autochthonous materials driving this variability (at least at the lower levels of the food web). Hydrologically variable rivers engender omnivory and trophic simplicity as adaptive strategies to seasonal resource variability, particularly for longer-lived fauna, such as fish (Poff and Allan 1995, Douglas et al. 2005, Pusey et al. 2010). Therefore, we predicted that
Burdekin catchment food webs would be characterized by omnivory, particularly among fishes, and that links between trophic levels would be short. To test our hypotheses, we used SCA, SIA with a mixing model (stableisotope analysis for R [SIAR]), and constructed food webs with measures of connectivity across all sampled sites.

\section{METHODS}

\section{Study area and sites}

The Burdekin catchment $\left(133,432 \mathrm{~km}^{2}\right.$; Fig. 1) is an important contributor of run-off to the Great Barrier Reef lagoon. Our study sites were in the middle reaches of the catchment, which consists of wooded savanna landscape used mainly for cattle grazing. The regional climate is wet-dry tropical with a summer wet season (NovemberMarch) during which flows are driven by monsoonal and cyclonic weather patterns, followed by a long dry season (May-October) during which flows diminish, often leaving

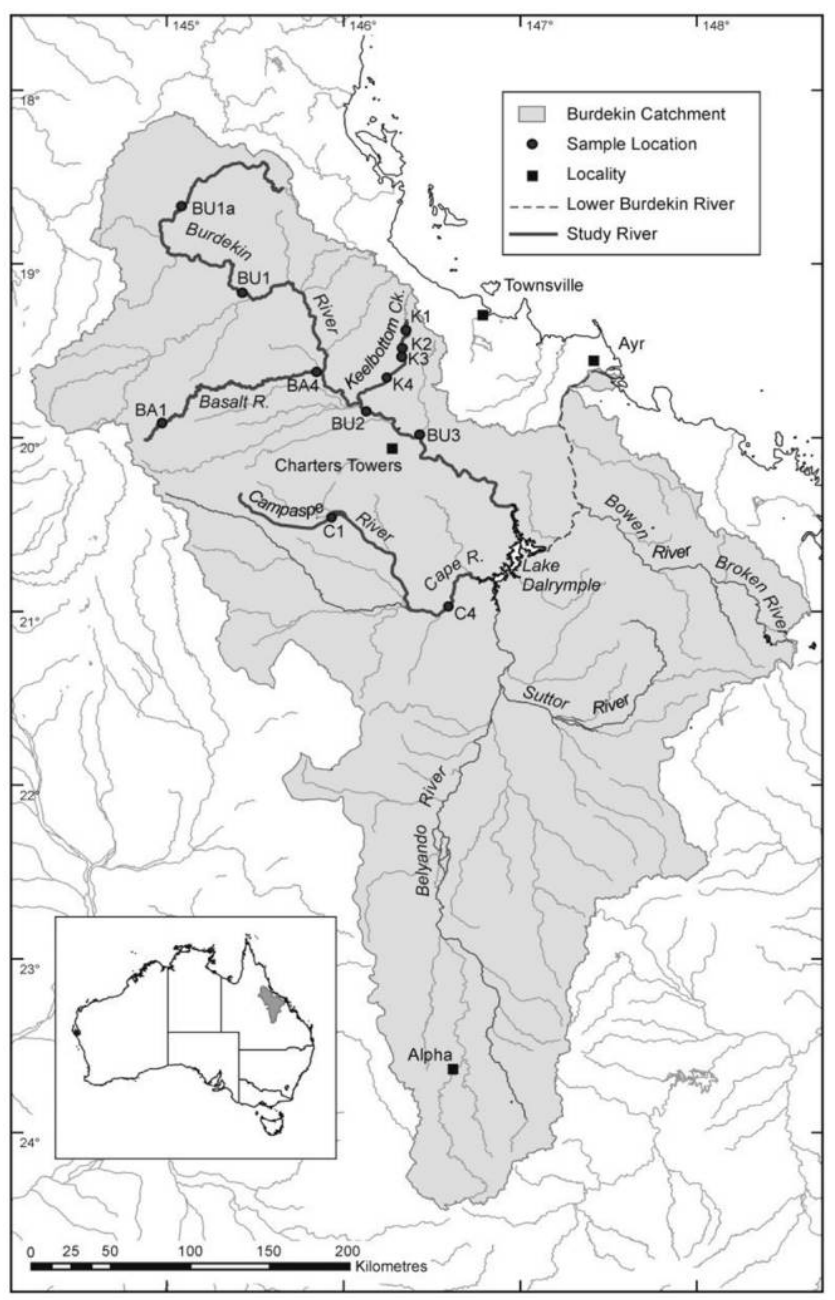

Figure 1. Map showing the locations of study sites in the Burdekin catchment, Queensland, Australia. 
hydrologically isolated waterholes along dry river beds (Kennard et al. 2010, Blanchette and Pearson 2012). Substantial variation in biophysical characteristics among rivers is caused by differences in weather pattern, lithology, and local factors (see Blanchette and Pearson 2012 for detailed site descriptions).

We sampled 12 sites in the Burdekin catchment: 4 on the Burdekin River and 8 on 3 tributaries (2 sites each on the Cape-Campaspe and Basalt Rivers and 4 sites on Keelbottom Creek) (Fig. 1). We selected sites for their hydrological permanence (information from landholders and gauging-station data), unimpounded location well upstream of the Burdekin Falls Dam, accessibility under most weather conditions, and representativeness of each river (assessed by preliminary site visits). However, sites within rivers were variable (Table 1; also see Blanchette and Pearson 2012). Spatial autocorrelation was unlikely to be a significant driving factor in our study because previous work demonstrated no effect of geographical distance between sites on macroinvertebrate assemblage composition (Blanchette and Pearson 2012). We sampled in the late dry season between September and December 2009 when rivers were most likely to be at their driest and, therefore, unlikely to be disturbed by floods. Each river had its own hydrological characteristics. Keelbottom Creek and the Cape-Campaspe River contracted longitudinally during the dry season, leaving a series of isolated water holes separated by dry river bed. The Basalt River also contracted substantially during the dry season, but was groundwater-fed and water holes were variously connected (although most connecting flows were insufficient to allow passage of larger fish). The Burdekin River was fed by ground water, and flowed throughout the dry season, with flows between sites generally sufficient to allow passage of larger fish.

We measured major physicochemical variables with a Hydrolab Quantum multiprobe meter (Hach/Hydrolab, Loveland, Colorado) and collected water samples for analysis at the Australian Centre for Tropical Freshwater Research at James Cook University (see Bainbridge et al. 2009). We assessed riparian-zone condition at each study site with the tropical rapid appraisal of riparian condition (TRARC) method, a multimetric index of pressure, condition, and vegetation cover developed for tropical Australian rivers (Dixon et al. 2006).

\section{Collection of samples for stable-isotope analysis}

We collected fish and large crustaceans with a boatmounted electrofisher (Model 2.5 GPP; Smith-Root, Vancouver, Washington) and gill nets in deep water (present at most sites) and a backpack electrofisher (Smith-Root Model 12B) in shallows with the aim of collecting the full range of size classes (following Pusey et al. 2010) for each species. Where possible, we conducted eight 5 -min passes with each electrofishing method in the sampled reach. We collected macroinvertebrates from all major in-stream habitats (edge, bed, macrophytes, riffle, run) with a dip net with $250-\mu \mathrm{m}$ mesh, picked them while they were alive, and placed them in distilled water for $\geq 3 \mathrm{~h}$ to facilitate purging of gut contents. We then rinsed animals with distilled water and stored them in plastic bags on ice for transport after pooling samples from different habitats at the site level. We froze all samples upon return to the laboratory. We collected zooplankton samples with 20 vertical hauls of a $63-\mu \mathrm{m}$ net through the water column, stored them in river water on ice for transport, and processed them on return to the laboratory.

We collected potential basal food sources (dominant terrestrial and aquatic vascular plants, submerged leaf litter, filamentous algae, seston) as follows. We clipped leaves of the dominant terrestrial and aquatic vascular plants at each site directly from the plant, rinsed them with distilled water, and stored them in plastic bags for transport. We collected submerged terrestrial leaf litter and filamentous algae from the substratum at each site. We collected seston (phytoplankton plus traces of particulate matter) by vertical hauls of a plankton net with $20-\mu \mathrm{m}$ mesh. Fine particulate organic matter (FPOM; $250 \mu \mathrm{m}$ to $<1 \mathrm{~mm}$ ) and coarse particulate organic matter $(\mathrm{CPOM} ; \geq 1 \mathrm{~mm})$ were collected by elutriating sediments on site. We then passed the organic matter through sieves ( $1 \mathrm{~mm}$ for CPOM, $250 \mu \mathrm{m}$ for FPOM) and rinsed it in distilled water. We collected epilithic biofilm by scrubbing 3 stones/site with a toothbrush and washed collected material through sieves (800and $250-\mu \mathrm{m}$ mesh sizes) to remove coarse detritus and macroinvertebrates. We placed the resultant slurry from each stone in individual tubes and stored them in the dark. We collected samples of the benthic Fe-fixing bacteria matrix (red flocculent; see Crerar et al. 1981) by hand at 3 points at the only site where they were present. We processed plankton samples immediately on return to the laboratory and then froze them. Other samples were stored on ice in the field and frozen on return to the laboratory.

\section{Laboratory processing and stable-isotope analysis}

We identified fish to species, measured (standard length) and weighed them, and conducted SCA per Davis et al. (2012a). We excised samples of abdominal muscle from larger decapod crustaceans and obtained tissue samples from snails and bivalves by crushing shells and excising muscles. We pooled all other macroinvertebrates by taxonomic or functional group (after Merritt and Cummins 1984, Cheshire et al. 2005; Table S1), and processed each group as a composite sample to attain adequate mass for isotope analysis. We oven-dried samples at $60^{\circ} \mathrm{C}$ for $96 \mathrm{~h}$, ground them to a fine powder with a mortar and pestle, and stored them at room temperature. 


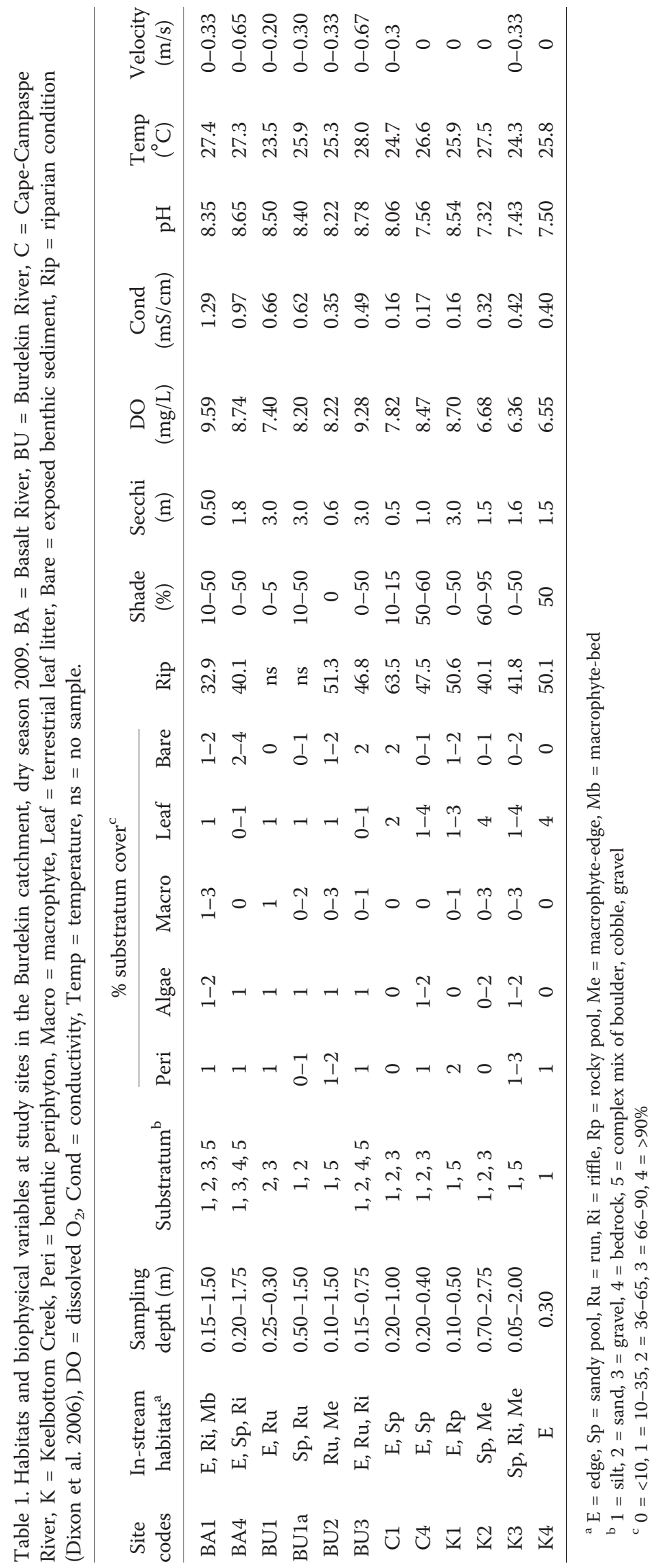


We rinsed aquatic and terrestrial vascular plants, CPOM, FPOM, Fe-fixing bacteria, and filamentous algae with distilled water and inspected material under a microscope to remove any contaminants (e.g., invertebrates) before oven-drying. We classified aquatic macrophytes as true aquatics or semiterrestrial following Sainty and Jacobs (1994) and Cowie et al. (2000). We processed zooplankton and seston samples before freezing. We poured each zooplankton sample through sieves (250 and $60 \mu \mathrm{m})$, rinsed them with distilled water, and retained the $60-\mu \mathrm{m}$ size fraction for analysis. We poured each seston sample through sieves $(60$ and $20 \mu \mathrm{m})$ to remove contaminants $>60 \mu \mathrm{m}$, rinsed them with distilled water, and retained the $20-\mu \mathrm{m}$ size fraction. We oven-dried these samples (as above) in Petri dishes. We centrifuged biofilm samples collected at each site at $\sim 1000 \mathrm{rpm}$ for $10 \mathrm{~min}$ and collected the chlorophyll-rich top fraction from each tube. We filtered this material through precombusted glass-fiber filter papers $(0.7 \mu \mathrm{m})$ and stored it frozen in aluminum foil until we oven-dried it. With the exception of the biofilm and plankton samples, we dried, finely ground, and stored plant material at room temperature.

Analysis for $\delta^{15} \mathrm{~N}, \delta^{13} \mathrm{C}, \% \mathrm{C}, \% \mathrm{~N}$, and $\mathrm{C}: \mathrm{N}$ was done by personnel at the Colorado Plateau Stable Isotope Laboratory (CPSIL) at Northern Arizona University. Samples were analyzed on a Thermo-Finnigan Delta Plus Advantage gas isotope-ratio mass spectrometer (see Davis et al. 2012a)

An emerging issue in SIA studies is the confounding effect of lipids, especially in fish tissues (Post et al. 2007, Logan et al. 2008). Therefore, isotopic analysis of duplicate samples (1 lipid-extracted, 1 bulk tissue) was conducted on $15 \%$ of samples from each size class of each fish species to develop a lipid-correction equation (Logan et al. 2008). Lipid extraction was performed by the CPSIL following a modified Folch et al. (1957) technique (Davis et al. 2012a).

\section{Data analyses}

In one family of fish (grunters [Terapontidae]), $\mathrm{C}: \mathrm{N}$ ratios were $>4$, indicating high lipid concentrations and necessitating lipid correction of $\delta^{13} \mathrm{C}$ using a family-specific equation:

$$
\begin{aligned}
\delta^{13} \mathrm{C}_{\text {normalized }}= & \delta^{13} \mathrm{C}_{\text {untreated }} \\
& +3.33 \log \left(\mathrm{C}: \mathrm{N}_{\text {bulk }}\right)-3.6219
\end{aligned}
$$

$\left(r^{2}=0.635\right)$. Other fish had $\mathrm{C}: \mathrm{N}$ ratios $<4$, so corrections were not required. Corrections were unnecessary for macroinvertebrates (Logan et al. 2008).

We used Stable Isotope Analysis in R (SIAR; Parnell et al. 2010), a Bayesian mixing model that runs on the $R$ platform (R Project for Statistical Computing, Vienna, Aus- tria) to estimate the contributions of different basal sources to consumer diets for each site. The advantage of using SIAR rather than other mixing models (e.g., IsoSource; Phillips and Greg 2003) is that it incorporates the inconsistencies and uncertainties associated with the data into the model and more accurately represents the variability inherent in the natural system (Parnell et al. 2010). The SIAR model is fit via the Markov Chain-Monte Carlo method to produce simulations of plausible values of dietary proportions of sources consistent with the data using a Dirichlet prior distribution (Jackson et al. 2009, Parnell et al. 2010). Each model was the product of 500,000 iterations, with the first 50,000 discarded. We report results as the 95\% confidence intervals (CIs; Phillips and Gregg 2003, Jackson et al. 2009, Parnell et al. 2010). Prior to analyses, we plotted consumer and source data with standard deviations to ensure that consumers were within the isotopic mixing space. We removed consumers that were outside the isotopic mixing space (after application of trophic enrichment values; see below) from further analyses.

We report SIAR results for consumers present at $\geq 50 \%$ of sites, which is a useful threshold for between-site comparison. We calculated standard deviations of source values for input into SIAR mainly from samples collected from the same site. However, not all sources were present at all sites, and only 1 sample each of filamentous algae and biofilm was analyzed per site. We calculated standard deviations in these cases with river- and then catchmentscale data (Table S2). Examination of data for each site indicated that some basal sources (e.g., CPOM and terrestrial C3 vegetation) could be combined (Bunn et al. 1999, Winemiller et al. 2007) using a conservative threshold of $2.0 \%$ between taxa. Conversely, 2 macrophyte species (Myriophyllum sp. and Potamogeton sp.) at site BA1 could not be combined with the aquatic macrophyte group and were treated individually.

Isotopes, especially of $\mathrm{N}$, exhibit a predictable trophic enrichment factor (TEF) between prey and consumer tissues, and the highest-level consumers generally have the most enriched tissue (DeNiro and Epstein 1981, Peterson and Fry 1987, Vander Zanden and Rasmussen 1999). SIAR includes TEF data to correct for the N-enriched status of consumers and places them within the N-depleted source-mixing geometry. We used TEF values for consumers and their putative diets calculated from Australian dryland/dry-tropics rivers (Bunn et al. 2013) to backcalculate basal-source mixtures. TEFs were as follows: herbivorous fish, $3.9 \pm 1.3(\mathrm{SD})$; predatory fish, $7.0 \pm 1.7$; herbivorous macroinvertebrates, $0.6 \pm 2.2$; predatory macroinvertebrates $1.8 \pm 1.9$. We excluded omnivores from analysis because of their highly variable TEF values. The $\Delta \delta^{15} \mathrm{~N}$ values of 0.6 and 1.8 are lower than the 2.3 to $3.4 \%$ commonly reported in the literature across multiple taxa and trophic levels (e.g., DeNiro and Epstein 1981, Minagawa 
and Wada 1984, McCutchan et al. 2003). However, Kilham et al. (2009) reported $\Delta \delta^{15} \mathrm{~N}$ values between 0.8 and 3.4\%o across food webs in tropical and temperate aquatic ecosystems, and McCutchan et al. (2003) found that $\delta^{15} \mathrm{~N}$ in consumers can vary depending on diet: $1.4 \pm 0.20 \%$ on macroinvertebrate and $3.3 \pm 0.26 \%$ on high-protein diets. Assigning discrete TEF values to herbivorous and predatory macroinvertebrates was straightforward because of their conservative dietary preferences, whereas fish were assigned to feeding groups on the basis of stomach-content analysis (see Davis et al. 2011) and previous studies (Jepsen and Winemiller 2002, Douglas et al. 2005, Pusey et al. 2010) because of their widespread omnivory in tropical rivers. Some species had large $\delta^{15} \mathrm{~N}$ values that placed them outside source-mixing polygons even after TEF correction, so we used alternative (nontrophic aligned) TEF values to place fishes within the source-mixing polygon (site-specific predator TEF used first, then $H$. fuliginosus size class 4 TEF $8.06 \pm 0.47$, which was the largest calculated TEF in our study). We assumed that if source contribution was influential enough in the mixing model, SIAR could account for the inconsistencies associated with the data, such as TEF variability and uncertainty (Parnell et al. 2010). We documented the TEF values and mixing-model results for all consumers to facilitate comparison across sites and taxa. $\mathrm{C}$ is relatively conserved across trophic levels, so we assumed a $\delta^{13} \mathrm{C}$ fractionation rate of $0.4 \pm 1.3 \%$ per trophic level, as did Post (2002) and Davis et al. (2012a). When analyzing outputs, we considered a source to be a likely contributor if its minimum contribution was $\geq 20 \%$ and a possible contributor if its minimum contribution was $>0 \%$ and its maximum was $\geq 50 \%$.

We standardized $\delta^{15} \mathrm{~N}$ for basal-source variability to calculate isotopic trophic position (ITP) for macroinvertebrates and fish. Plotting the values of primary consumers establishes a baseline relationship between these isotopic values for a given system that can then be used to calculate ITP for each individual based on its $\delta^{13} \mathrm{C}$ and $\delta^{15} \mathrm{~N}$ (Vander Zanden and Rasmussen 1999, Jardine et al. 2013). It is necessary to account for this relationship to determine ITP of higher consumers because many individuals consume a variety of sources that differ in baseline $\delta^{15} \mathrm{~N}$ (Vander Zanden and Rasmussen 1999). $\delta^{15} \mathrm{~N}_{\text {base }}$ for a consumer was calculated from its corresponding raw $\delta^{13} \mathrm{C}$ value as

$$
\delta^{13} \mathrm{~N}_{\text {base }}=-1.850-0.196\left(\delta^{13} \mathrm{C}\right)
$$

derived from primary-consumer baseline relationships $\left(r^{2}=\right.$ $0.177, p<0.001)$. Primary consumers in our study were: zooplankton, Ephemeroptera (Baetidae, Caenidae, Leptophlebiidae), Coleoptera (Psephenidae, Hydrophilidae, Hydrochidae, Curculionidae, Elmidae, Hydraenidae), nonpredatory Trichoptera (Calamoceratidae, Leptoceridae:Triplectides),
Lepidoptera, Decapoda (Atyidae), Gastropoda (Thiaridae, Corbiculidae, Hyriidae), and Diptera (Simuliidae, Culicidae). We calculated the isotopic trophic positions of macroinvertebrates and fish with the equation used by Winemiller et al. (2007):

$$
\operatorname{ITP}=\left(\frac{\left[\delta^{15} \mathrm{~N}_{\text {consumer }}-\delta^{15} \mathrm{~N}_{\text {base }}\right]}{\Delta^{15} \mathrm{~N}}\right)+2
$$

where $\Delta^{15} \mathrm{~N}$ is the average change in $\delta^{15} \mathrm{~N}$ per trophic level based on the trophotaxon-specific diet-tissue fractionation values published by Bunn et al. (2013). We used 1-way analysis of variance (ANOVA) with Tukey's post hoc test (SigmaPlot 11, Systat Software Inc., San Jose, California) to identify differences in ITPs of herbivorous, predatory, and omnivorous fishes (classified by stomachcontent analysis and Pusey et al. 2004, 2010) across all sites.

We estimated trophic position of fishes from stomachcontent data (STP) with the equation published by Winemiller et al. (2007):

$$
\operatorname{STP}_{i}=\sum_{j=1}^{n} \mathrm{TL}_{j}\left(\mathrm{p}_{j}\right)+1
$$

where $\mathrm{STP}_{i}$ is the trophic position of target consumer $i$, $\mathrm{TL}_{j}$ is the trophic level of prey taxon $j$, and $\mathrm{p}_{j}$ is the volumetric contribution of prey species $j$. We based trophic levels of prey items on the dominant functional group of most of the members of a taxon (macroinvertebrates: Merritt and Cummins 1984, Cheshire et al. 2005; fishes: Pusey et al. 2010, our study). We coded primary producers (algae, vegetation, detritus, sediment) as $\mathrm{TL}=1$ and primary consumers (Ephemeroptera, Hydrophilidae, Elmidae, Lepidoptera, Orthoptera, Cladocera, Mollusca, and the fishes $\mathrm{Ne}$ matalosa erebi and Oreochromis mossambicus) as TL $=2$. We coded secondary consumers (Odonata, Ceratopogonidae, Tabanidae, Naucoridae, Gerridae, Veliidae, Dytiscidae, Acarina, and the fishes Craterocephalus stercusmuscarum, Oxyeleotris lineolatus, and Ambassis spp.) as TL $=3$. We coded omnivores (Chironomidae, Simuliidae, Corixidae, Formicidae, macrocrustacea, Copepoda, Ostracoda, the fish Melanotaenia splendida, unidentified fish, and fish eggs) as $\mathrm{TL}=2.5$, while recognizing that the ratio of plant to animal consumption is unlikely to be strictly $1: 1$ (and that not all members may feed in the same trophic group). We explored the relationship between STP and ITP by linear regression.

\section{Food webs}

We constructed food webs for each site based on major links between foodweb components (nodes). We considered a basal-source node present if components were available in sufficient quantities for SIA (applies mainly to autochthonous material). A consumer was 'present' if 
$\geq 1$ individual was collected from a site. We placed consumers in 1 of 10 categories: zooplankton, detritus shredders, live-plant shredders/scrapers, benthic scrapers, benthic gatherers/filter collectors, predatory macroinvertebrates, terrestrial/semiterrestrial macroinvertebrates, herbivorous fishes, omnivorous fishes, or predatory fishes. We added links according to SCA (fish only) and review of the literature. We did not use consumer ITPs to add links. We designated macroinvertebrates (and their links) according to the feeding groups of Merritt and Cummins (1984), Chessman (1986), and Gooderham and Tsyrlin (2002), and we grouped fishes as herbivores, predators, or omnivores according to SCA (Pusey et al. 2010, our study). We did not include other top predators (e.g., water birds and turtles) in these food webs. We estimated the relative complexity of each food web by calculating the connectance of the webs and their component groups as a proportion of the maximum possible connectance (Pimm 1984, Pimm et al. 1991). Following Cheshire et al. (2005), we calculated link number as the actual number of links, $S$ as the number of elements in the food web (consumers + basal sources), maximum link as the maximum number of links possible in the food web $(S[S-1] / 2)$, and connectance as the number of links/maximum number of links.

\section{RESULTS}

Across all sites, basal sources were the most N-depleted, fish were the most $\mathrm{N}$-enriched, and macroinvertebrates were intermediate (Fig. 2). Basal sources were separated according to $\mathrm{C}$ value. The $\mathrm{C} 4$ grass Cynodon dactylon (Poaceae) had a $\delta^{13} \mathrm{C} \approx-13 \%$, and the rest of the sources (mostly C3 vegetation) had $\delta^{13} \mathrm{C}$ values between -20 and $-35 \%$ (Fig. S1A). With the exception of C. dactylon, different sources tended to overlap, especially filamentous algae with semiaquatic macrophytes and filamentous algae with FPOM/seston. Tree species within genera (e.g., Melaleuca and Eucalyptus) did not always have similar $\delta^{13} \mathrm{C}$ values, and values for filamentous algae varied greatly. $\delta^{13} \mathrm{C}$ values of macrophyte species tended to group according to habit (true aquatic, e.g., Potamogeton spp. or semiterrestrial, e.g., Persicaria decipiens) (Fig. S1B).

Among the consumers, herbivorous macroinvertebrates (e.g., Ephemeroptera) were N-depleted, and predators (e.g., Acarina, Odonata, some Hemiptera and Coleoptera) were N-enriched (Fig. S2A). Detritivores, scavengers, filter feeders, and omnivores (notably the Bivalvia [Fig. S2A] and Decapoda [Fig. S2B]) also were $\mathrm{N}$-enriched. This pattern was repeated in the fishes. Herbivores (Nematalosa erebi and Oreochromis mossambicus) usually were N- and C-depleted (Fig. S3), but 3 omnivorous/herbivorous terapontids (Hephaestus fuliginosus, Scortum parviceps, Leiopotherapon unicolor) were the most $\mathrm{C}$ - and $\mathrm{N}$-enriched.
Falling between these 2 groups were the predators, which had the greatest range of $\delta^{13} \mathrm{C}$ and $\delta^{13} \mathrm{~N}$ values.

The SIAR mixing calculations were notable for the high level of source fidelity within individual sites by different consumer taxa (Tables 2, 3). For both macroinvertebrates and fish, 7 of the 9 sites with multiple significant results had only 1 type of likely or possible basal source per site, despite the presence of a wide range of taxa and potential sources. Sites varied in their dominant basal sources even within a river: for example, the main source at sites BU1, BU1a, and BU2 was terrestrial C3 vegetation, but at site BU3 it was filamentous algae. Semiaquatic macrophytes were an important source for fish at site $\mathrm{C} 1$ and for macroinvertebrates and fishes at site BA4. At site BA1, macroinvertebrates were strongly aligned with filamentous algae, as was the herbivorous fish $\mathrm{Ne}$ matalosa erebi. However, the diet of Amniataba percoides, also at site BA1, appeared to be based on terrestrial C3 vegetation. At site $\mathrm{K} 2$, macroinvertebrates and the fish Mogurnda adspersa were aligned with Fe-fixing bacteria. Sources at site K4 were consistent within but not between consumer groups (macroinvertebrates: terrestrial C3 vegetation and semiaquatic macrophytes, fish: C4 grasses).

High proportions of macroinvertebrates (72\%) and fish $(87 \%)$ had unresolved mixing models (Tables 2, 3). Only $10 \%$ of the unresolved models for macroinvertebrates were the result of consumers being outside the source-mixing polygon, a result indicating that most unresolved models resulted from omnivory or lack of source differentiation (even between autochthonous and allochthonous sources). For example, at site BA1, filamentous algae and submerged terrestrial leaves (dominant species Eucalyptus camaldulensis) were not well differentiated $\left(\delta^{13} \mathrm{C}=\right.$ -31.37 and -29.87 , respectively). At site K3, filamentous algae and submerged Melaleuca leucadendra leaves were not well differentiated $\left(\delta^{13} \mathrm{C}=-31.89\right.$ and -32.45 , respectively). Only $7 \%$ of the unresolved models for fishes were outside the source-mixing polygons after application of alternative TEFs. The remaining unresolved fish models were within the source-mixing polygons with (19\%) or without (74\%) alternative TEFs.

ITP of macroinvertebrates varied among sites, even within a taxon (Table S3; also shows site-specific taxonomic groups). Decapods (particularly Palaemonidae) generally had the highest ITP (3.18-5.06). Little consistency was observed at the lower and middle trophic positions, although the Odonata (Hemicorduliidae, Urothemistidae, Libellulidae) had the lowest ITP at 4 sites (ITP $=1.25-$ 3.23).

ITP of fish also varied among sites and within species (Table S4). However, one trophotaxon (Hephaestus fuliginosus size class 4) had the highest ITP (3.53-4.81) at 6 of 8 sites. ITP differed significantly among herbivores, omnivores, and carnivores across all sites $\left(F_{407}=26.35, p<0.001\right)$. 


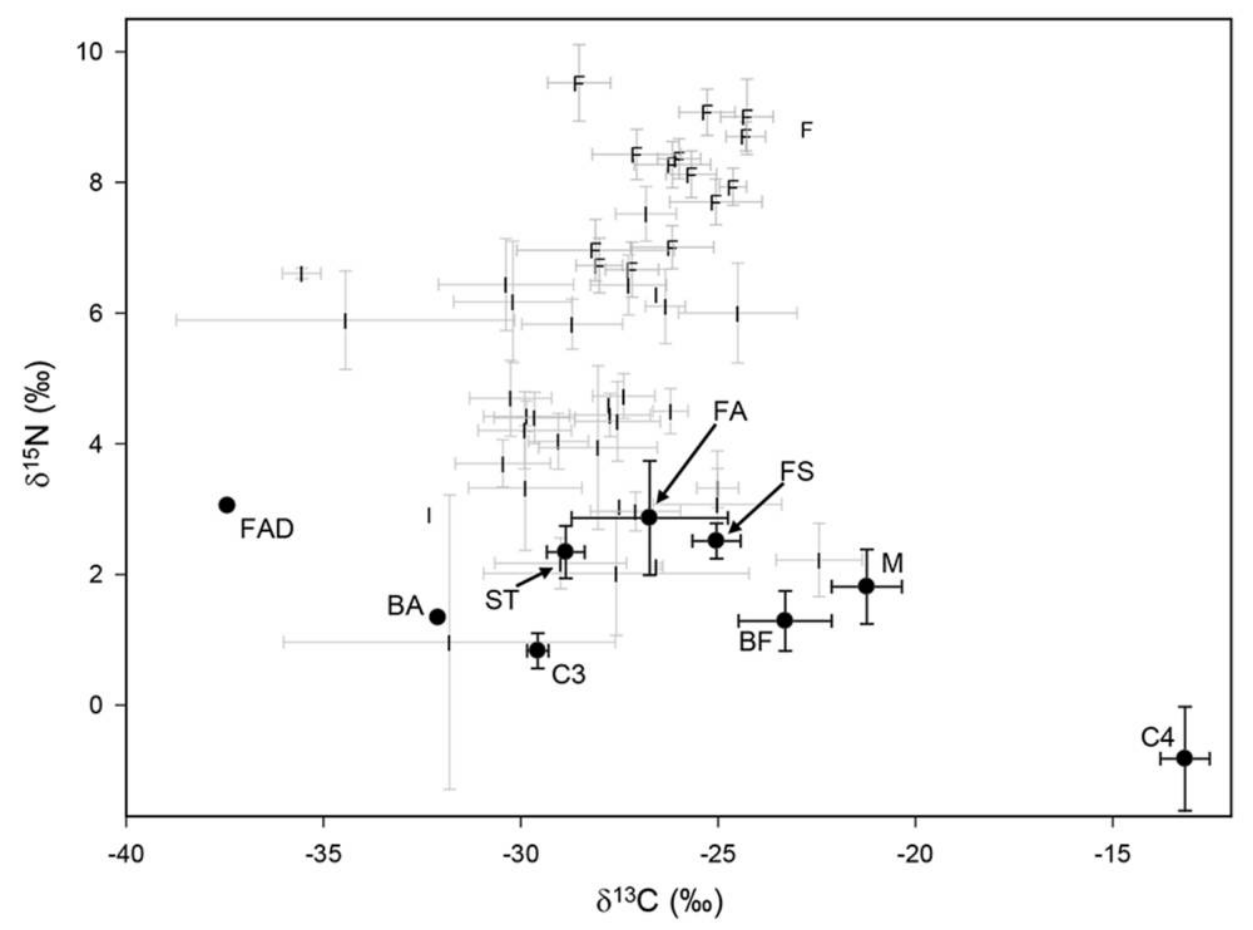

Figure 2. Mean ( $\pm 1 \mathrm{SD}) \delta^{13} \mathrm{C}$ and $\delta^{15} \mathrm{~N}$ ratios of basal sources, fish (F), and invertebrates (I) collected from all sites. Basal source codes are: $\mathrm{FA}=$ filamentous algae, $\mathrm{ST}=$ semiterrestrial macrophytes, $\mathrm{FS}=$ fine particulate organic matter and seston, $\mathrm{C} 3=$ terrestrial $\mathrm{C} 3$ vegetation, $\mathrm{BF}=$ biofilm, $\mathrm{M}=$ true aquatic macrophytes, $\mathrm{C} 4=\mathrm{C} 4$ terrestrial grasses, $\mathrm{BA}=\mathrm{Fe}$-fixing bacteria, $\mathrm{FAD}=\mathrm{C}^{13}$-depleted filamentous algae. Each consumer point represents a unique taxon.

Table 2. Results of stable isotope analysis for R (SIAR) mixing model for invertebrates collected from each site. Abbreviations indicate dominant basal source (see Fig. 4 for abbreviations). Bold $=\geq 20 \%$ minimum contribution to mixing model, regular type $=<20 \%$ minimum contribution and maximum contribution $\geq 50 \%, \mathrm{n}=$ not resolved (equal contribution of sources, isotopic source overlap, or consumer outside basal-source polygon). See Table 1 for site abbreviations. - indicates consumer not found at site.

\begin{tabular}{|c|c|c|c|c|c|c|c|c|c|c|c|c|c|}
\hline \multirow[b]{2}{*}{ Taxon } & \multirow[b]{2}{*}{ Family } & \multicolumn{12}{|c|}{ Site } \\
\hline & & BU1 & BU1a & BU2 & BU3 & $\mathrm{C} 1$ & $\mathrm{C} 4$ & BA1 & BA4 & K1 & K2 & K3 & K4 \\
\hline Bivalvia & Corbiculidae & - & $\mathrm{n}^{\mathrm{a}}$ & - & $\mathrm{n}$ & - & $\mathrm{n}$ & FA & - & - & - & - & - \\
\hline \multirow[t]{2}{*}{ Coleoptera } & Dytiscidae & $\mathrm{C} 3$ & $\mathrm{C} 3$ & - & $\mathrm{n}$ & $\mathrm{n}$ & $\mathrm{n}$ & FA & $\mathrm{n}$ & $\mathrm{n}$ & $\mathrm{n}$ & $\mathrm{n}$ & $\mathrm{n}$ \\
\hline & Hydrophilidae and Hydrochidae & $\mathrm{n}$ & - & $\mathrm{n}$ & $\mathrm{n}$ & $\mathrm{n}$ & $\mathrm{n}$ & $\mathrm{n}$ & $\mathrm{n}$ & - & - & $\mathrm{n}$ & $\mathrm{n}$ \\
\hline \multirow[t]{2}{*}{ Ephemeroptera } & Baetidae & - & - & $\mathrm{n}$ & $\mathrm{n}$ & - & - & FA & $\mathrm{n}$ & - & - & - & - \\
\hline & Caenidae & - & - & - & $\mathrm{n}$ & $\mathrm{n}^{\mathrm{a}}$ & $\mathrm{n}$ & - & $\mathrm{n}$ & $\mathrm{n}$ & BA & - & C3, ST \\
\hline Gastropoda & Thiaridae & $\mathrm{n}$ & $\mathrm{C} 3$ & - & $\mathrm{n}$ & - & - & $\mathrm{n}$ & - & $\mathrm{n}$ & - & - & - \\
\hline Hemiptera & Mixed predators & $\mathrm{C} 3$ & - & $\mathrm{n}$ & $\mathrm{n}$ & $\mathrm{n}$ & $\mathrm{n}$ & FA & $\mathrm{n}$ & $\mathrm{n}$ & $\mathrm{n}$ & $\mathrm{n}$ & $\mathrm{n}$ \\
\hline Lepidoptera & & - & - & $\mathrm{n}^{\mathrm{a}}$ & FAD & - & - & $\mathrm{n}^{\mathrm{a}}$ & $\mathrm{n}$ & - & $\mathrm{n}$ & - & - \\
\hline Arachnida & Acarina & - & - & - & - & $\mathrm{n}^{\mathrm{a}}$ & $\mathrm{n}$ & - & $\mathrm{ST}$ & - & BA & - & - \\
\hline \multirow[t]{4}{*}{ Odonata } & Coenagrionidae & $\mathrm{C} 3$ & C3 & $\mathrm{n}$ & $\mathrm{n}$ & - & $\mathrm{n}$ & FA & - & $\mathrm{n}$ & - & $\mathrm{n}$ & C3, ST \\
\hline & Gomphidae & $\mathrm{C} 3$ & - & $\mathrm{C} 3$ & FAD & $\mathrm{n}^{\mathrm{a}}$ & $\mathrm{n}$ & $\mathrm{n}$ & $\mathrm{n}$ & $\mathrm{n}$ & BA & $\mathrm{n}$ & C3, ST \\
\hline & $\mathrm{H}, \mathrm{U}, \mathrm{L}^{\mathrm{b}}$ & $\mathrm{C} 3$ & $\mathrm{C} 3$ & $\mathrm{n}$ & $\mathrm{n}$ & $\mathrm{n}$ & $\mathrm{n}$ & FA & $\mathrm{n}$ & $\mathrm{n}$ & BA & $\mathrm{n}$ & C3 \\
\hline & Leptoceridae & - & C3 & $\mathrm{n}$ & $\mathrm{n}$ & - & $\mathrm{n}$ & $\mathrm{n}$ & $\mathrm{n}$ & $\mathrm{n}$ & BA & $\mathrm{n}$ & $\mathrm{n}$ \\
\hline
\end{tabular}

${ }^{\text {a }}$ Consumer outside source geometry

${ }^{\mathrm{b}}$ Hemicorduliidae, Urothemistidae, Libellulidae 
Table 3. Results of stable isotope analysis for R (SIAR) mixing model for fish collected from each site. Taxon size classes follow Pusey et al. (2010). Abbreviations indicate dominant basal source (see Fig. 4 for abbreviations). Bold $=\geq 20 \%$ minimum contribution to mixing model, regular type $=<20 \%$ minimum contribution and maximum contribution $\geq 50 \%, \mathrm{n}=$ not resolved (equal contribution of sources, isotopic source overlap, or consumer outside basal-source polygon). See Table 1 for site abbreviations. - indicates consumer not found at site.

\begin{tabular}{|c|c|c|c|c|c|c|c|c|c|c|c|c|}
\hline \multirow[b]{2}{*}{ Taxon (size class) } & \multicolumn{12}{|c|}{ Site } \\
\hline & BU1 & BU1a & BU2 & BU3 & $\mathrm{C} 1$ & $\mathrm{C} 4$ & BA1 & BA4 & K1 & K2 & K3 & K4 \\
\hline Ambassis agrammus (2) & - & $\mathrm{n}$ & - & - & $n^{\mathrm{b}}$ & $n^{b}$ & $\mathrm{n}$ & - & $\mathrm{n}$ & $\mathrm{n}$ & - & - \\
\hline Amniataba percoides (2) & - & $\mathrm{n}$ & $\mathrm{n}$ & - & - & - & $\mathrm{C} 3^{\mathrm{b}}$ & ST & $n^{3}$ & $\mathrm{n}$ & $\mathrm{n}$ & $\mathrm{N}$ \\
\hline Hephaestus fuliginosus (4) & $\mathrm{n}^{\mathrm{a}}$ & $\mathrm{n}$ & $\mathrm{n}$ & $\mathrm{n}$ & $\mathrm{n}^{\mathrm{a}}$ & - & $\mathrm{n}$ & - & $\mathrm{n}$ & $\mathrm{n}$ & - & - \\
\hline Leiopotherapon unicolor (1) & - & $\mathrm{n}$ & $\mathrm{n}$ & $\mathrm{n}$ & $\mathrm{n}^{\mathrm{a}}$ & $n^{b}$ & - & $\mathrm{n}$ & $\mathrm{n}$ & $\mathrm{n}$ & $\mathrm{n}$ & $\mathrm{n}^{\mathrm{a}}$ \\
\hline Leiopotherapon unicolor (3) & $\mathrm{n}$ & $\mathrm{n}$ & $\mathrm{n}$ & $\mathrm{n}$ & $\mathrm{n}^{\mathrm{a}}$ & - & $\mathrm{n}$ & $\mathrm{n}$ & $\mathrm{n}$ & $\mathrm{n}$ & $\mathrm{n}^{\mathrm{a}}$ & $\mathrm{C4}^{\mathrm{b}}$ \\
\hline Melanotaenia splendida (1) & $\mathrm{C} 3$ & $\mathrm{n}$ & $\mathrm{n}$ & - & $n^{\mathrm{b}}$ & $n^{b}$ & $\mathrm{n}$ & - & $\mathrm{n}$ & - & $\mathrm{n}$ & $\mathrm{N}$ \\
\hline Melanotaenia splendida (3) & - & $\mathrm{n}$ & $\mathrm{n}$ & - & $n^{\mathrm{b}}$ & - & $\mathrm{n}$ & $\mathrm{n}$ & $\mathrm{n}$ & $\mathrm{n}$ & $\mathrm{n}^{\mathrm{a}}$ & $\mathrm{C}^{\mathrm{b}}$ \\
\hline Mogurnda adspersa (2) & - & - & - & - & $n^{\mathrm{b}}$ & $n^{b}$ & $\mathrm{n}$ & - & $\mathrm{n}$ & BA & $\mathrm{n}$ & $\mathrm{C4}$ \\
\hline Nematalosa erebi (3) & - & - & $\mathrm{n}$ & - & $\mathrm{n}^{\mathrm{a}}$ & - & $\mathrm{C} 3^{\mathrm{b}}$ & $\mathrm{n}$ & $\mathrm{n}$ & - & $\mathrm{n}$ & - \\
\hline Neosilurus ater (4) & - & $\mathrm{n}$ & $\mathrm{n}$ & $\mathrm{n}$ & $\mathbf{S T}^{\mathbf{b}}$ & - & - & $\mathrm{n}$ & $\mathrm{n}$ & $\mathrm{n}$ & - & - \\
\hline Neosilurus hyrtlii (3) & - & $\mathrm{n}$ & - & - & $\mathbf{S T}^{\mathbf{b}}$ & $n^{b}$ & - & - & - & $\mathrm{n}$ & $\mathrm{n}$ & $\mathrm{n}$ \\
\hline Neosilurus mollespiculum (4) & - & - & - & - & - & - & - & $n^{\mathrm{b}}$ & - & - & - & - \\
\hline Oreochromis mossambicus (2) & $\mathrm{n}$ & - & - & - & - & $n^{b}$ & - & $\mathrm{n}$ & - & $\mathrm{n}$ & $\mathrm{n}$ & $\mathrm{n}^{\mathrm{c}}$ \\
\hline Oreochromis mossambicus (4) & - & $\mathrm{C} 3$ & - & FA & $\mathrm{n}^{\mathrm{b}}$ & - & - & - & $\mathrm{n}$ & $\mathrm{n}$ & $\mathrm{n}$ & - \\
\hline Oxyeleotris lineolatus (2) & - & $\mathrm{n}$ & $\mathrm{n}$ & $\mathrm{n}$ & $\mathrm{ST}^{\mathrm{b}}$ & - & - & $\mathrm{n}$ & $\mathrm{C} 3$ & $\mathrm{n}$ & - & $\mathrm{n}^{\mathrm{a}}$ \\
\hline Oxyeleotris lineolatus (4) & $\mathrm{n}$ & $\mathrm{n}$ & $\mathrm{n}$ & $\mathrm{n}$ & $\mathrm{n}^{\mathrm{b}}$ & $n^{\mathrm{b}}$ & - & - & $\mathrm{n}$ & $\mathrm{n}$ & $\mathrm{n}$ & $\mathrm{C4}^{\mathrm{b}}$ \\
\hline Scortum parviceps (2) & - & $n^{b}$ & - & $\mathrm{n}$ & - & - & - & - & - & - & - & - \\
\hline Scortum parviceps (3) & - & $\mathrm{n}$ & - & $\mathrm{n}$ & - & - & - & - & - & - & - & - \\
\hline Scortum parviceps (4) & - & - & $n^{2}$ & - & $\mathrm{ST}^{\mathrm{b}}$ & - & - & $\mathrm{n}$ & - & - & - & - \\
\hline
\end{tabular}

The differences were associated with herbivorous fishes. ITPs of omnivores and carnivores did not differ (Tukey's post hoc test $p=0.205)$, but herbivores differed significantly from both $(p<0.001)$ and generally had lower ITPs (mean herbivore ITP $=3.00 \pm 0.591$, omnivore ITP $=3.60 \pm 0.47$, carnivore ITP $3.36 \pm 0.43$ ). Little consistency in ITP values was found at the lower and middle trophic positions for fish.

STP of fish varied among sites, even within the same species (Table S5). STP differed significantly among herbivores, omnivores, and carnivores $\left(F_{317}=62.91, p<0.001\right)$, with all groups significantly different from each other (Tukey's post hoc test, $p<0.003)$. STP and ITP were not correlated within species, and they were correlated at only 2 sites: BA4 $\left(p=0.011, r^{2}=0.179\right)$, and K4 $\left(p=0.024, r^{2}=\right.$ 0.266).

Omnivory occurred throughout the food web and was most prevalent at the top, where omnivorous fishes were numerous and fed at all trophic levels. Relative to other taxonomic groups, omnivorous fishes also had the most potential connectivity (Fig. 3). Feeding across multiple trophic levels also was characteristic of many of the mac- roinvertebrate taxa collected, particularly the aquatic predators and semiterrestrial spiders, which varied among sites (Fig. 4). Within invertebrate feeding groups (especially the live-plant shredders/scrapers and benthic gatherers/filter collectors), taxa were able to exploit multiple basal sources at different sites (Fig. 4). Overall, foodweb structure differed among sites mainly because of the presence or absence of 2 basal sources (filamentous algae and Fe-fixing bacteria) and particular primary consumers (zooplankton, shredders, aquatic macrophyte consumers) (Table S6, Fig. 4). The higher consumer levels were represented at all sites.

The average connectance across sites was $0.320 \pm 0.04$, with BU1a having the lowest connectance $(0.231)$ and $\mathrm{K} 3$ having the highest connectance (0.385) (Table 4, Fig. 4).

\section{DISCUSSION}

Omnivory was a major feature of the food webs in the seasonal rivers of the Burdekin catchment, and connections between consumers and prey items were short. We hypoth- 


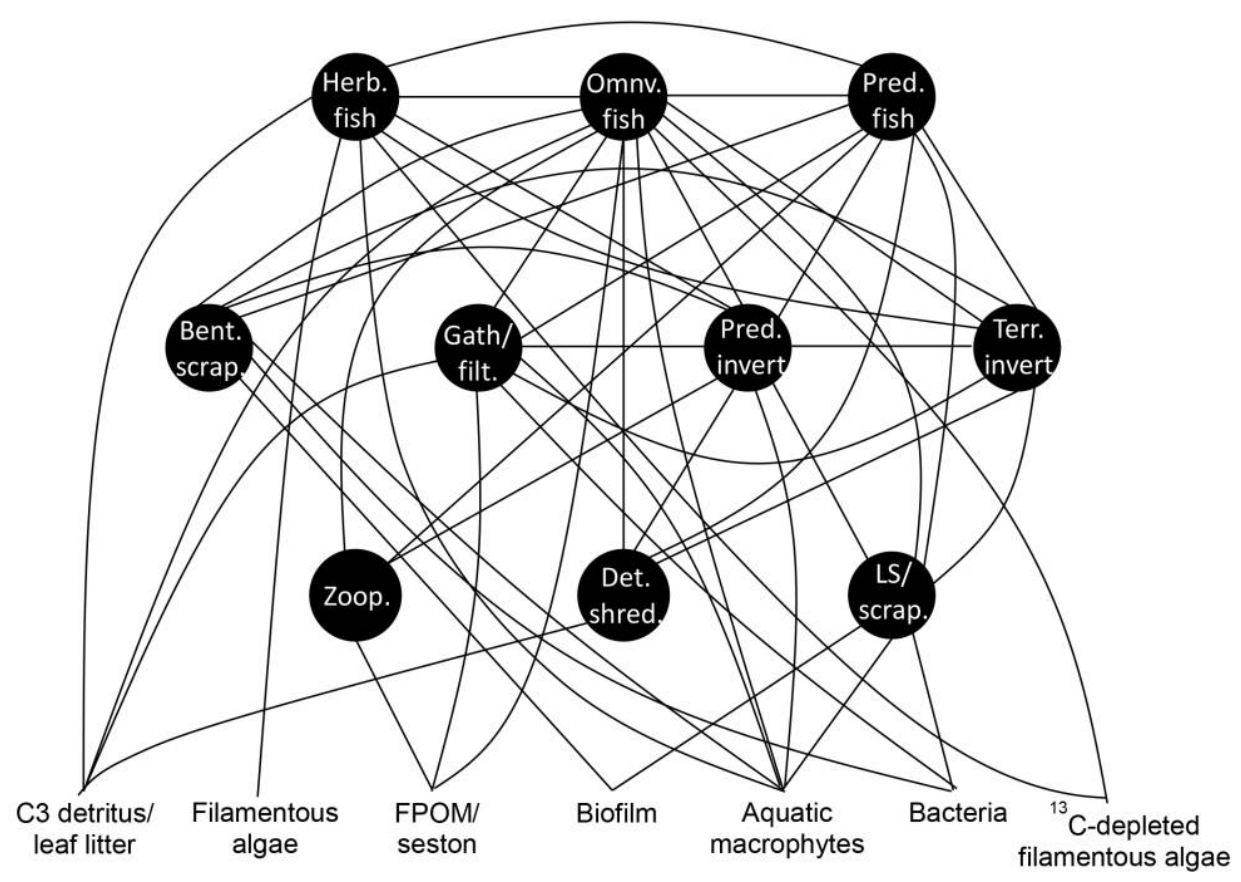

Figure 3. Burdekin River foodweb template showing maximum connectivity of major components (consumers and basal source) across all sites. Abbreviations in circles represent consumer feeding groups/trophic levels: Zoop. = zooplankton, Det. shred. $=$ detrital shredders, LS/scrap. = live plant shredders and scrapers, Bent. scrap. = benthic scrapers, Gath/filt. = benthic gatherers and filter collectors, Pred. invert $=$ predatory invertebrates, Terr. Invert $=$ terrestrial $/$ semiterrestrial invertebrates, Herb. fish $=$ herbivorous fishes, Omniv. fish = omnivorous fishes, Pred. fish = predatory fishes. Basal source: $\mathrm{FPOM}=$ fine particulate organic matter.

esized that, particularly for fish, omnivory would be widespread. We found that the use of stable isotopes in this variable system resulted in many unresolved mixing models (for fish and invertebrates), and occasionally poor differentiation among basal sources. Therefore, we support the use of complementary techniques (such as SCA) to enhance the outcomes of stable-isotope studies (e.g., Beaudoin et al. 1999, Mantel et al. 2004, Davis et al. 2012a). Complementary techniques can provide useful comparisons, even if a potential mismatch exists between STP and ITP because of seasonal opportunism in feeding (Beaudoin et al. 1999).

Omnivory in dry-tropics rivers may be an adaptation to seasonally variable hydrological conditions (Winemiller 2004, Douglas et al. 2005, Leigh et al. 2010, Pusey et al. 2010) because dietary specialization is more prevalent when food sources are predictable (Pusey et al. 2010). Widespread omnivory among fishes of the Burdekin River has been recorded previously, although spatial variability in diets was low (Pusey et al. 2010). STP of fish in our study indicated that diets varied within some fish trophospecies across sites, as did foodweb structure and connectance. The results obtained by Pusey et al. (2010) differ from ours and those of other studies in which diets of fishes differed spatially according to habitat structure and prey availability (Pusey et al. 1995, Romanuk et al. 2006), even within reaches (Rayner et al. 2009). Pusey et al. (2010) attributed this disparity in the Burdekin River to a lack of in-stream habitat structure (floodplains, back- waters, riffles, rapids), but we found diverse habitats and varying hydrological conditions among sites. These contrasting results may reflect different temporal conditions, or simply methodological and fine-scale habitat variability. Despite these incongruent findings, omnivory, especially in fish, clearly is characteristic of dry-tropics river assemblages.

Foodweb structure differed mainly in the presence or absence of particular primary consumers and basal sources, with some food webs driven by allochthonous $\mathrm{C}$ and others by autochthonous sources, such as filamentous algae, even among sites within the same river. We hypothesized that basal-source importance would be patchy within and among rivers as a function of local-scale biophysical variability (especially riparian condition). It is tempting to equate availability of basal sources with their relative importance in the food web (e.g., Vannote et al. 1980), but this relationship was inconsistent across sites. For example, Keelbottom Creek had extensive canopy cover and large accumulations of terrestrial leaf litter in the stream, but mixing-model analysis identified a variety of sources, with $\mathrm{C} 3$ vegetation only weakly important for macroinvertebrates at 1 site. In contrast, C3 vegetation was consistently important at the Burdekin River sites, despite varying canopy cover and leaf-litter input. In a subalpine Colorado stream, $C$ assimilated by consumers did not reflect its availability because terrestrial C3 vegetation was important in the food webs despite little canopy cover (McCutchan and 

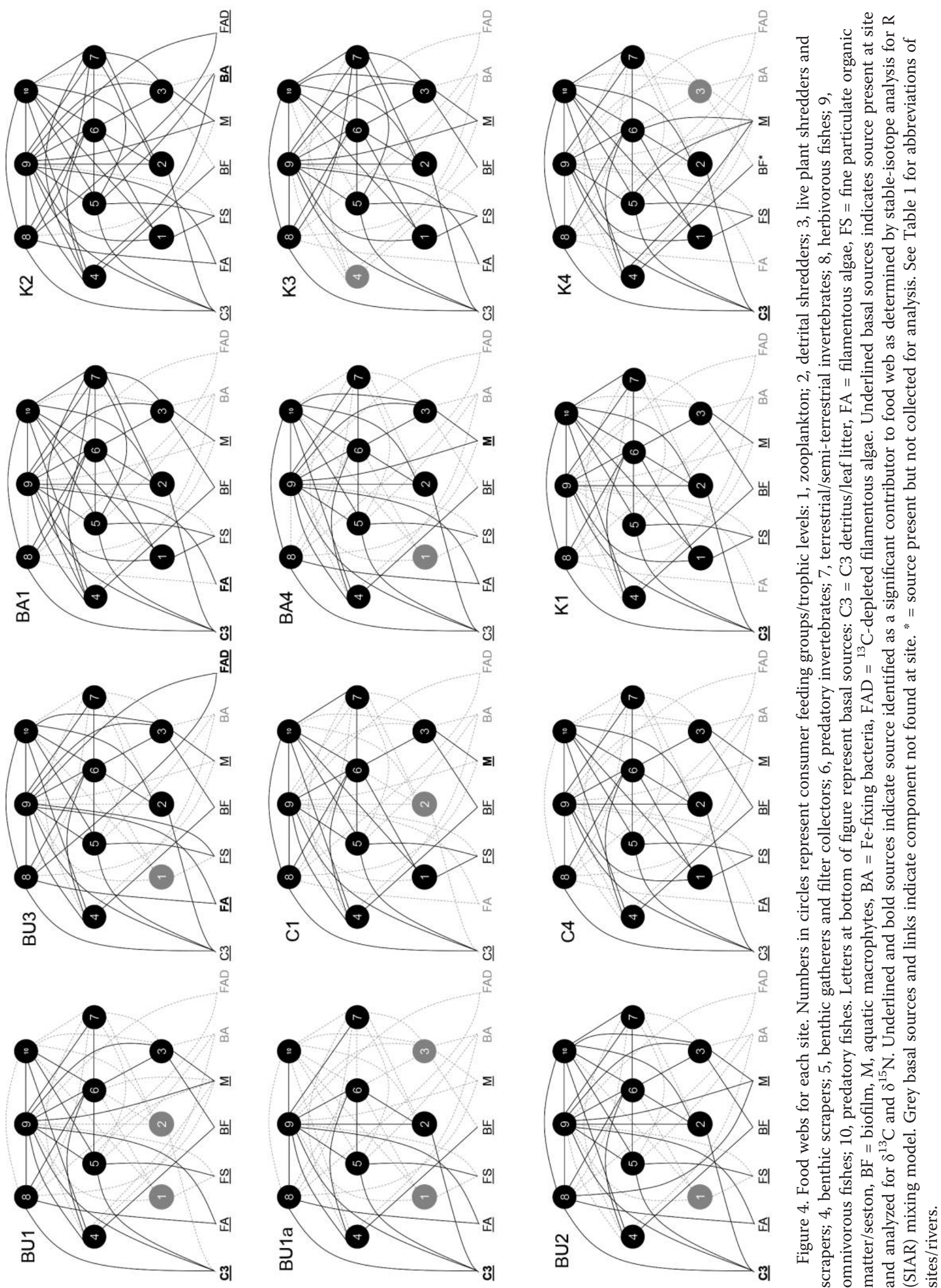
Table 4. Foodweb connectance at sites in the Burdekin catchment, organized by connectance (as per Pimm 1984, Pimm et al. 1991, and see Cheshire et al. 2005). Links is actual number of links, $S$ is number of elements in the web (consumers plus basal sources), Max. links is maximum number of links possible in web according to $S(S-1) / 2$, connectance is number of links/maximum number of links. Also shown is mean connectance (with standard deviation [SD]) across all sites. Sites as per Table 1.

\begin{tabular}{lcccc}
\hline Site & Links & $S$ & Max. links & Connectance \\
\hline BU1a & 18 & 13 & 78 & 0.231 \\
C4 & 27 & 15 & 105 & 0.257 \\
BU3 & 32 & 15 & 105 & 0.305 \\
BA4 & 28 & 14 & 91 & 0.308 \\
K2 & 43 & 17 & 136 & 0.316 \\
K1 & 29 & 14 & 91 & 0.319 \\
BU1 & 25 & 13 & 78 & 0.321 \\
C1 & 25 & 13 & 78 & 0.321 \\
BU2 & 32 & 14 & 91 & 0.352 \\
BA1 & 37 & 15 & 105 & 0.352 \\
K4 & 29 & 13 & 78 & 0.372 \\
K3 & 35 & 14 & 91 & 0.385 \\
Mean & & & & 0.320 \\
SD & & & & 0.044 \\
\hline
\end{tabular}

Lewis 2002). At lower elevations in this Colorado stream, where allochthonous litter was abundant, benthic algae were more important sources of $\mathrm{C}$ (McCutchan and Lewis 2002). In a forested stream in tropical Queensland, stableisotope data indicated that consumers were more dependent on epilithic algae than terrestrial vegetation and that filamentous algae and aquatic macrophytes did not contribute to the broader food web (Bunn et al. 1999). This tropical Queensland study assumed that sites from 3 streams in the same catchment ('biome') were sufficiently similar to be replicates. Streams from a small catchment might possibly be less spatially diverse than large dry-tropics rivers, but our data and those of others (e.g., McCutchan and Lewis 2002) show that we cannot assume that conditions at individual sites can be extrapolated to larger scales or that data can be reliably compared to reference sites to determine baseline ecological function (Sheldon 2005, Blanchette and Pearson 2012, 2013). In the case of stableisotope studies, we cannot rely on basal-source availability as a proxy for basal-source importance.

The importance of terrestrial C3 vegetation at some sites and the basal-source variability throughout the catchment, contrasts with the findings from some other dryland and dry-tropics river foodweb studies that identify autochthonous material as the most important dry-season C source (Bunn et al. 2003, Douglas et al. 2005, Fellows et al.
2007, Jardine et al. 2013). This view differs from the notion of floodplain connectivity, whereby floodplain-derived terrestrial vegetation supports food webs for at least part of the year (Junk et al. 1989, Junk and Wantzen 2004). In a hydrologically variable Texas river, terrestrial C3 vegetation supported most consumers, but important $\mathrm{C}$ sources varied with flow regime (Zeug and Winemiller 2008). These results concur with other Australian wet-dry tropics studies (Leigh et al. 2010, Hunt et al. 2012) where terrestrial or floodplain sources can be important in riverine food webs, and the importance of different basal sources can be spatially and temporally variable.

In addition to predicted basal sources (e.g., leaf litter and filamentous algae), isotopic mixing models identified some surprising $\mathrm{C}$ sources, such as Fe-fixing bacteria at site $\mathrm{K} 2$ and aquatic macrophytes at sites $\mathrm{C} 1, \mathrm{BA} 4$, and K4. Site K2 was blanketed with a thick layer of bacteria at the time of sampling, and basal sources could have been contaminated by the bacteria, which were inadvertently ingested by consumers. However, previous investigators using SIA (e.g., Sarbu et al. 1996, Opsahl and Chanton 2006, Roach et al. 2011) have described the importance of microbes to freshwater metazoans, although their research mainly occurred in light-limited subterranean caves. Clearly, more research is needed to describe the influence of microbes on freshwater food webs. We found that, consistent with gut contents, aquatic macrophytes were important sources for macroinvertebrates and fish at some sites (cf. Watson and Barmuta 2011). However, others have reported that macroinvertebrates do not assimilate aquatic macrophytes (e.g., Hamilton et al. 1992, Bunn and Boon 1993). We suggest that macrophytes be considered as potential sources when collecting data for foodweb studies, and field sampling regimes should be flexible enough to take advantage of unanticipated $C$ sources.

We did not find good agreement between ITP and STP, a result that probably was a reflection of the contrasting temporal and physiological attributes characteristic of both methods. Stable-isotope analysis provides a direct measure of tissue assimilation and is a longer-term indication of diet than gut-content analysis (Winemiller et al. 2007) because of lags in material assimilation (Fry and Arnold 1982, Herzka and Holt 2000, McIntyre and Flecker 2006). For longer-lived animals, especially those that are migratory, isotopic composition may reflect their feeding in environments other than where they were collected (Jackson and Harkness 1987, Herzka 2005) and hydrological connectivity between sites (Jardine et al. 2012). This consideration is important when using mixing models to estimate the contribution of food sources because models assume that consumer tissues are in isotopic equilibrium with the sources present at time of collection (Martinez del Rio et al. 2009, Codron et al. 2012). Moreover, many fishes display size-related dietary shifts, e.g., 
juveniles of most terapontid species are invertivorous, but become carnivorous, omnivorous, herbivorous, or detritivorous as they grow (Davis et al. 2011). These transitions also are affected by habitat and environmental variability (Davis et al. 2012b). The temporal effects of assimilation on such species are unclear, but a significant lag time coupled with migration probably would affect source-consumer equilibrium (e.g., Jardine et al. 2012) and, hence, calculation of ITP. Feeding experiments are needed to correct for differential assimilation between taxa and among tissue types (Gannes et al. 1997, Martinez del Rio et al. 2009) and to allow for more robust comparisons between stomachcontent and SIA approaches.

Temporal variability in basal-source use is likely to be more apparent lower in the food web where organisms are shorter-lived. Food webs at all sites had representatives of the higher-level consumers (omnivores and predators), but differed mainly in connectance because of the presence (or absence) of particular taxa at some sites. Therefore, despite variation in basal sources among sites, food webs were similar at the top. Dryland-river fish are hardy, but assemblages are species-poor compared to nearby wet-tropical assemblages (e.g., Pusey and Kennard 1996), and consumer persistence and mobility could have affected the relative importance of basal sources. For example, in another Australian tropical river, within-channel benthic algae supported macroinvertebrates during the dry season, whereas higher consumers may have assimilated a floodplain C source (Hunt et al. 2012). Therefore, the relatively long-lived fishes may reflect interannual processes (including hydrological connectivity) and spatial variability of $\mathrm{C}$ sources, whereas macroinvertebrates, with shorter generation times, reflect more recent, local conditions and basal sources (Jardine et al. 2012). Thus, generation time and prevailing environmental conditions may partly explain variability among sites at the base of the food webs.

Despite this variability, herbivores were generally $\mathrm{N}$ depleted, predators were generally N-enriched, and omnivores varied, as expected (e.g., Minagawa and Wada 1984, Fry 1988). Notably, the omnivorous macroinvertebrates and the omnivorous-herbivorous terapontid $H$. fuliginosus were highly $\mathrm{N}$-enriched, even in comparison with the top predators. It is not uncommon for isotopic values to overestimate trophic position in herbivores and omnivores (Carseldine and Tibbetts 2005, Layman et al. 2005a, Mill et al. 2007, Winemiller et al. 2011). Given that our SCAs concurred with those of Pusey et al. (2010), this result may have been partly caused by assimilation by animals of invertebrate biomass and voiding of refractory detritus (Winemiller et al. 2007).

Despite our care in separating sources and consumers, the characteristics of the system under study (high spatial and temporal ecological variability, basal-source similarity) precluded definitive answers to some stable- isotope questions, at least at some sites. In addition, the use of isotopic mixing models has its own challenges. In the absence of feeding trials, assumed TEF values are widely applied in most ecological studies, despite the fact that this assumption has been cited as a potential source of error in modeling (Caut et al. 2009, Bond and Diamond 2011). We used the trophic-level-specific TEF values published by Bunn et al. (2013) (and, in some cases, nontrophic-aligned TEF values derived from our study) rather than the same average value for every consumer, but our values were still assumed and, therefore, were potential sources of error. One of the advantages of SIAR is that it operates under Bayesian assumptions and can readily account for variation in trophic fractionation (Parnell et al. 2010). However, SIAR is not insensitive to variability in fractionation (Bond and Diamond 2011). One strategy is to exclude $\mathrm{N}$ from isotope mixing models in favor of other elements, such as C and S (e.g., Melville and Connolly 2005, Benstead et al. 2006, Leigh et al. 2010), which have smaller trophic fractionation values (McCutchan et al. 2003).

Comparison of foodweb structure among different ecosystems or studies is hampered by an unequal distribution of variables (Pimm et al. 1991, Vermaat et al. 2009) and different levels of taxonomic resolution (Mantel et al. 2004, Cheshire et al. 2005). In our study, connectance varied among sites, even within the same river. Cheshire et al. (2005) found that in upland rainforest tributaries of the Burdekin catchment, overall connectance of the invertebrate food web varied between 0.19 and 0.26 (cf. $0.23-$ 0.39 in our study). Lowland tributaries of the Burdekin may appear to be more highly connected than the rainforest reaches, but whether these data are directly comparable is unclear because different methods were used in the 2 studies (e.g., animal collection, taxonomic resolution). We used binary trophic links (i.e., a link is either present or absent) to construct food webs. However, binary methods may be hampered by an absence of direct quantitative measurements of energy flow (e.g., biomass, productivity) and, therefore, the relative importance of each link. On the other hand, the difficulty of quantifying every energetic relationship in a food web can obfuscate the broader measurement of energy transfer. Ideal foodweb studies should incorporate both flow- and binary-based data to test the influence of multiple variables on foodweb metrics (Cheshire et al. 2005).

Ecosystem robustness, or the ability of a food web to withstand random extinctions, is thought to increase as overall foodweb connectivity increases (Dunne et al. 2002). In highly omnivorous food webs, removal of one wellconnected taxon may have little overall effect on the food web, whereas removal of many of these taxa may cause further extinctions (Mantel et al. 2004). In our study, the absence of a few key taxa (e.g., zooplankton and semiterrestrial fishing spiders) appeared to affect connectance strongly 
at the site level, consistent with theoretical expectations of their strong leverage in food webs (Dunne et al. 2002). Zooplankters provide a critical link between seston and the broader food web, and semiterrestrial spiders facilitate aquatic-terrestrial linkage. In contrast, omnivorous fish provided most links in the food web, but the loss of any one of these taxa had little effect because omnivory was common to several species. Species losses of $\geq 20 \%$ often are required before effects are propagated to the broader food web as secondary extinctions (Dunne et al. 2002). These results suggest that dry-tropical river food webs will be able to withstand perturbations provided that complementary, highly connected species are retained.

\section{Conclusions}

The SIAR model tended to work best at sites where basal-source groupings were isotopically distinct and sources could be grouped confidently according to habitat (e.g., terrestrial or aquatic) with minimal variability. In our study, the model did not consistently differentiate between autochthonous sources, and at some sites, autochthonous and allochthonous materials had similar $\delta^{13} \mathrm{C}$ values. Such are the well known problems of stable-isotope-based studies of food webs, and our understanding of them is restricted accordingly. Unfortunately, some authors appear not to report such issues. Appropriate conclusions and future improvements in stable-isotope ecology depend on reporting variability and anomalies in the data.

Our study has confirmed the inherent variability of drytropics rivers (Blanchette and Pearson 2012, 2013). During the dry season, spatial variability occurred in basal-source contribution to food webs, trophic position of individual taxa, and foodweb structure, with sites from the same river often as different as sites from different rivers. Therefore, our study is unusual because it highlights this variability of sources across sites in the same catchment (cf. Bunn et al. 2003, Douglas et al. 2005, Fellows et al. 2007, Jardine et al. 2013). The high variability in dryland river ecology may be a response to variable flow regimes, with food webs exhibiting dynamic stability (Leigh et al. 2010) that allows species to persist in the face of harsh environmental conditions. Our study supports this idea, especially at the top of the food web, where omnivorous fishes were found consistently at sites with different basal sources and primary consumers.

\section{ACKNOWLEDGEMENTS}

We thank landowners and property managers for allowing access to sites and for their hospitality and support, and we thank the many people in the region who offered advice, assistance, and encouragement. We thank our many volunteer assistants. The map of the Burdekin catchment was provided by
Adella Edwards, James Cook University School of Earth and Environmental Science, with data from Geoscience Australia. Water-quality samples were analyzed by the Australian Centre for Tropical Freshwater Research at James Cook University, and we particularly thank Brett Baker and Michelle Tink. Stableisotope analysis was done at the Colorado Plateau Stable Isotope Laboratory at Northern Arizona University, USA, and we thank Mark Doucette and Melanie Caron for their assistance. We also thank Don Phillips for early conversations about isotope mixing models, and Betsy Jackes and Nanette Hooker for assistance with identification of plant material. MB thanks Mark Lund and the Mine Water and Environment Research Centre at Edith Cowan University for support during the final phase of writing. Funding was provided by the Australian Commonwealth's Marine and Tropical Science Research Facility and by the School of Marine and Tropical Biology at James Cook University (JCU). Fish were collected under JCU ethics approval A1076, and Queensland Department of Primary Industries collection permit PRM00274G. We thank 2 anonymous referees and the editors of Freshwater Science for their helpful comments on this manuscript.

\section{LITERATURE CITED}

Anderson, N. H., and J. R. Sedell. 1979. Detritus processing by macroinvertebrates in stream ecosystems. Annual Review of Entomology 24:351-377.

Bainbridge, Z. T., J. E. Brodie, J. W. Faithful, D. A. Sydes, and S. E. Lewis. 2009. Identifying the land-based sources of suspended sediments, nutrients and pesticides discharged to the Great Barrier Reef from the Tully-Murray Basin, Queensland, Australia. Marine and Freshwater Research 60:1081-1090.

Beaudoin, C. P., W. M. Tonn, E. E. Prepas, and L. I. Wassenaar. 1999. Individual specialization and trophic adaptability of northern pike (Esox lucius): an isotope and dietary analysis. Oecologia (Berlin) 120:386-396.

Benfield, E. F., and J. R. Webster. 1985. Shredder abundance and leaf breakdown in an Appalachian Mountain stream. Freshwater Biology 15:113-120.

Benstead, J. P., J. G. March, B. Fry, K. C. Ewel, and C. M. Pringle. 2006. Testing IsoSource: stable isotope analysis of a tropical fishery with diverse organic matter sources. Ecology 87:326-333.

Blanchette, M. L., and R. G. Pearson. 2012. Macroinvertebrate assemblages in rivers of the Australian dry tropics are highly variable. Freshwater Science 31:865-881.

Blanchette, M. L., and R. G. Pearson. 2013. Dynamics of habitats and macroinvertebrate assemblages in rivers of the Australian dry tropics. Freshwater Biology 58:742-757.

$\rightarrow$ Bond, A. L., and A. W. Diamond. 2011. Recent Bayesian stableisotope mixing models are highly sensitive to variation in discrimination factors. Ecological Applications 21:1017-1023.

Bunn, S. E., and P. I. Boon. 1993. What sources of organic carbon drive food webs in billabongs? A study based on stable isotope analysis. Oecologia (Berlin) 96:85-94.

Bunn, S. E., P. M. Davies, and T. D. Mosisch. 1999. Ecosystem measures of river health and their response to riparian and catchment degradation. Freshwater Biology 41:333-345. 
Bunn, S. E., P. M. Davies, and M. Winning. 2003. Sources of organic carbon supporting the food web of an arid zone? floodplain river. Freshwater Biology 48:619-635.

Bunn, S. E., C. Leigh, and T. D. Jardine. 2013. Diet-tissue fractionation of $\delta^{15} \mathrm{~N}$ by consumers from streams and rivers. Limnology and Oceanography 58:765-773.

Carseldine, L., and I. R. Tibbetts. 2005. Dietary analysis of the herbivorous hemiramphid Hyporhamphus regularis ardelio: an isotopic approach. Journal of Fish Biology 66:1589-1600.

Caut, S., E. Angulo, and F. Courchamp. 2009. Variation in discrimination factors $\left(\delta^{15} \mathrm{~N}\right.$ and $\left.\delta^{13} \mathrm{C}\right)$ : the effect of diet isotopic values and applications for diet reconstruction. Journal of Applied Ecology 46:443-453.

Cheshire, K., L. Boyero, and R. G. Pearson. 2005. Food webs in tropical Australian streams: shredders are not scarce. Freshwater Biology 50:748-769.

Chessman, B. C. 1986. Dietary studies of aquatic insects from two Victorian rivers. Australian Journal of Marine and Freshwater Research 37:129-146.

$\rightarrow$ Codron, D., M. Sponheimer, J. Codron, I. Newton, J. L. Lanham, and M. Clauss. 2012. The confounding effects of source isotopic heterogeneity on consumer-diet and tissuetissue stable isotope relationships. Oecologia (Berlin) 169 939-953.

Cowie, I. D., P. S. Short, and M. Osterkamp Madsen. 2000. Floodplain flora: a flora of the coastal floodplains of the Northern Territory, Australia. Australian Biological Resources Study, Canberra, Australia.

Crerar, D. A., J. L. Means, R. F. Yuretich, M. P. Borcsik, J. L. Amster, D. W. Hastings, G. W. Knox, K. E. Lyon, and R. F. Quiett. 1981. Hydrogeochemistry of the New Jersey Coastal Plain: 2. Transport and deposition of iron, aluminum, dissolved organic matter, and selected trace elements in stream, ground- and estuary water. Chemical Geology 33:23-44.

Davis, A. M., M. L. Blanchette, B. J. Pusey, T. D. Jardine, and R. G. Pearson. 2012a. Gut-content and stable-isotope analyses provide complementary understanding of ontogenetic dietary shifts and trophic relationships among fishes in a tropical river. Freshwater Biology 57:2156-2172.

$\rightarrow$ Davis, A. M., R. G. Pearson, B. J. Pusey, C. Perna, D. L. Morgan, and D. Burrows. 2011. Trophic ecology of northern Australia's terapontids: ontogenetic dietary shifts and feeding classification. Journal of Fish Biology 78:265-286.

$\rightarrow$ Davis, A. M., B. J. Pusey, and R. G. Pearson. 2012b. Contrasting intraspecific dietary shifts in two terapontid assemblages from Australia's wet-dry tropics. Ecology of Freshwater Fish 21:42-56.

DeNiro, M. J., and S. Epstein. 1981. Influence of diet on the distribution of nitrogen isotopes in animals. Geochimica et Cosmochimica Acta 45:341-353.

Dixon, I., M. Douglas, J. Dowe, and D. Burrows. 2006. Tropical rapid appraisal of riparian condition version 1 (for use in tropical savannahs). River and Riparian Land Management Technical Guideline 7:1-36.

$\rightarrow$ Douglas, M. M., S. E. Bunn, and P. M. Davies. 2005. River and wetland food webs in Australia's wet-dry tropics: general principles and implications for management. Marine and Freshwater Research 56:329-342.
Dunne, J. A., R. J. Williams, and N. D. Martinez. 2002. Network structure and biodiversity loss in food webs: robustness increases with connectance. Ecology Letters 5:558-567.

Fellows, C. S., M. L. Wos, P. C. Pollard, and S. E. Bunn. 2007. Ecosystem metabolism in a dryland river waterhole. Marine and Freshwater Research 58:250-262.

Finlay, J. C. 2001. Stable carbon isotope ratios of river biota: implications for energy flow in lotic food webs. Ecology 82:10521064.

Folch, J., M. Lees, and G. H. Sloane Stanley. 1957. A simple method for the isolation and purification of total lipids from animal tissues. Journal of Biological Chemistry 226:497-509.

Fry, B. 1988. Food web structure on Georges Bank from stable $\mathrm{C}, \mathrm{N}$, and $\mathrm{S}$ isotopic compositions. Limnology and Oceanography 33:1182-1190.

$\rightarrow$ Fry, B., and C. Arnold. 1982. Rapid ${ }^{13} \mathrm{C} /{ }^{12} \mathrm{C}$ turnover during growth of brown shrimp (Penaeus aztecus). Oecologia (Berlin) 54:200-204.

Gannes, L. Z., D. M. O’Brien, and C. Martinez del Rio. 1997. Stable isotopes in animal ecology: assumptions, caveats, and a call for more laboratory experiments. Ecology 78:1271-1276.

Gooderham, J., and E. Tsyrlin. 2002. The waterbug book: a guide to the freshwater macroinvertebrates of temperate Australia. CSIRO Publishing, Melbourne, Australia.

Hamilton, S. K., W. M. Lewis, Jr, and S. J. Sippel. 1992. Energy sources for aquatic animals in the Orinoco River floodplain: evidence from stable isotopes. Oecologia (Berlin) 89:324-330.

Herzka, S. Z. 2005. Assessing connectivity of estuarine fishes based on stable isotope ratio analysis. Estuarine, Coastal, and Shelf Science 64:58-69.

Herzka, S. Z., and G. J. Holt. 2000. Changes in isotopic composition of red drum (Sciaenops occelatus) larvae in response to dietary shifts: potential applications to settlement studies. Canadian Journal of Fisheries and Aquatic Sciences 57:137-147.

Hunt, R. J., T. D. Jardine, S. K. Hamilton, and S. E. Bunn. 2012. Temporal and spatial variation in ecosystem metabolism and food web carbon transfer in a wet-dry tropical river. Freshwater Biology 57:435-450.

Hyslop, E. J. 1980. Stomach contents analysis-a review of methods and their application. Journal of Fish Biology 17:411-429.

Jackson, A. L., R. Inger, S. Bearhop, and A. Parnell. 2009. Erroneous behaviour of MixSIR, a recently published Bayesian isotope mixing model: a discussion of Moore and Semmens, Ecology Letters, 2008. Ecology Letters 12:E6-E8.

Jackson, D., and D. D. Harkness. 1987. The use and interpretation of $\delta^{13} \mathrm{C}$ values as a means of establishing dietary composition. Oikos 48:258-264.

Jardine, T. D., R. J. Hunt, S. J. Faggotter, D. Valdez, M. A. Burford, and S. E. Bunn. 2013. Carbon from periphyton supports fish biomass in waterholes of a wet-dry tropical river. River Research and Applications 29:560-573.

Jardine, T. D., N. E. Pettit, D. M. Warfe, B. J. Pusey, D. P. Ward, M. M. Douglas, P. M. Davies, and S. E. Bunn. 2012. Consumer-resource coupling in wet-dry tropical rivers. Journal of Animal Ecology 81:310-322.

Jepsen, D. B., and K. O. Winemiller. 2002. Structure of tropical river food webs revealed by stable isotope ratios. Oikos 96 : $46-55$. 
Junk, W. J., P. B. Bayley, and R. E. Sparks. 1989. The flood pulse concept in river-floodplain systems. Special Publication of the Canadian Journal of Fisheries and Aquatic Sciences 106: $110-127$.

Junk, W. J., and K. M. Wantzen. 2004. The flood pulse concept: new aspects, approaches, and applications-an update. Pages 117-140 in R. Welcomme and T. Petr (editors). Proceedings of the $2^{\text {nd }}$ International Symposium on the Management of Large Rivers for Fisheries. Volume II. Food and Agricultural Organization of the United Nations \& the Mekong River Commission, Phnom Penh, Cambodia.

Kennard, M. J., B. J. Pusey, J. D. Olden, S. J. MacKay, J. L. Stein, and N. Marsh. 2010. Classification of natural flow regimes in Australia to support environmental flow management. Freshwater Biology 55:171-193.

Kilham, S. S., M. Hunte-Brown, P. Verburg, C. M. Pringle, M. R. Whiles, K. R. Lips, and E. Zandona. 2009. Challenges for interpreting stable isotope fractionation of carbon and nitrogen in tropical aquatic ecosystems. Verhandlungen der Internationalen Vereinigung für theoretische und angewandte Limnologie 30:749-753.

Layman, C. A., K. O. Winemiller, and D. A. Arrington. 2005 a. Describing the structure and function of a Neotropical river food web using stable isotopes, stomach contents, and functional experiments. Pages 395-406 in P. C. de Ruiter, V. Wolters, and J. C. Moore (editors). Dynamic food webs: multispecies assemblages, ecosystem development and environmental change. Elsevier, Amsterdam, The Netherlands.

Layman, C. A., K. O. Winemiller, D. A. Arrington, and D. B. Jepsen. 2005b. Body size and trophic position in a diverse tropical food web. Ecology 86:2530-2535.

Leigh, C., M. A. Burford, F. Sheldon, and S. E. Bunn. 2010. Dynamic stability in dry season food webs within tropical floodplain rivers. Marine and Freshwater Research 61:357-368.

Logan, J. M., T. D. Jardine, T. J. Miller, S. E. Bunn, R. A. Cunjak, and M. E. Lutcavage. 2008. Lipid corrections in carbon and nitrogen stable isotope analyses: comparison of chemical extraction and modelling methods. Journal of Animal Ecology 77:838-846.

Mantel, S. K., M. Salas, and D. Dudgeon. 2004. Food web structure in a tropical Asian forest stream. Journal of the North American Benthological Society 23:728-755.

Martinez del Rio, C., N. Wolf, S. A. Carleton, and L. Z. Gannes. 2009. Isotopic ecology ten years after a call for more laboratory experiments. Biological Reviews 84:91-111.

McCutchan, J. H., and W. M. Lewis, Jr. 2002. Relative importance of carbon sources for macroinvertebrates in a Rocky Mountain stream. Limnology and Oceanography 47:742-752.

McCutchan, J. H., W. M. Lewis, Jr, C. Kendall, and C. C McGrath. 2003. Variation in trophic shift for stable isotope ratios of carbon, nitrogen, and sulfur. Oikos 102:378-390.

McIntyre, P. B., and A. S. Flecker. 2006. Rapid turnover of tissue nitrogen of primary consumers in tropical freshwaters. Oecologia (Berlin) 148:12-21.

Melville, A. J., and R. M. Connolly. 2005. Food webs supporting fish over subtropical mudflats are based on transported organic matter not in situ microalgae. Marine Biology 148: 363-371.
Merritt, R. W., and K. W. Cummins (editors). 1984. An introduction to the aquatic insects of North America. $2^{\text {nd }}$ edition. Kendall/Hunt, Dubuque, Iowa.

Mill, A. C., J. K. Pinnegar, and N. V. C. Polunin. 2007. Explaining isotope trophic-step fractionation: why herbivorous fish are different. Functional Ecology 2:1137-1145.

$\rightarrow$ Minagawa, M., and E. Wada. 1984. Stepwise enrichment of ${ }^{15} \mathrm{~N}$ along food chains: further evidence and the relation between $\delta^{15} \mathrm{~N}$ and animal age. Geochimica et Cosmochimica Acta 48:1135-1140.

Opsahl, S. P., and J. P. Chanton. 2006. Isotopic evidence for methane-based chemosynthesis in the Upper Floridian aquifer food web. Oecologia (Berlin) 150:89-96.

Parkyn, S. M., K. J. Collier, and B. J. Hicks. 2001. New Zealand stream crayfish: functional omnivores but trophic predators? Freshwater Biology 46:641-652.

$\rightarrow$ Parnell, A. C., R. Inger, S. Bearhop, and A. L. Jackson. 2010. Source partitioning using stable isotopes: coping with too much variation. PLoS ONE 5:e9672.

Peterson, B. J., and B. Fry. 1987. Stable isotopes in ecosystem studies. Annual Review of Ecology and Systematics 18:293320.

Pettit, N. E., P. Bayliss, P. M. Davies, S. K. Hamilton, D. M. Warfe, S. E. Bunn, and M. M. Douglas. 2011. Seasonal contrasts in carbon resources and ecological processes on a tropical floodplain. Freshwater Biology 56:1047-1064.

Phillips, D. L., and J. W. Gregg. 2003. Source partitioning using stable isotopes: coping with too many sources. Oecologia (Berlin) 136:261-269.

Pimm, S. L. 1984. The complexity and stability of ecosystems. Nature 307:321-326.

Pimm, S. L., J. H. Lawton, and J. E. Cohen. 1991. Food web patterns and their consequences. Nature 350:669-674.

Poff, N. L., and J. D. Allan. 1995. Functional organization of stream fish assemblages in relation to hydrological variability. Ecology 76:606-627.

Post, D. M. 2002. Using stable isotopes to estimate trophic position: models, methods, and assumptions. Ecology 83:703-718.

Post, D. M., C. A. Layman, D. A. Arrington, G. Takimoto, J. Quattrochi, and C. G. Montana. 2007. Getting to the fat of the matter: models, methods, and assumptions for dealing with lipids in stable isotope analysis. Oecologia (Berlin) 152:179-189.

Pusey, B. J., A. H. Arthington, B. Stewart-Koster, M. J. Kennard, and M. G. Read. 2010. Widespread omnivory and low temporal and spatial variation in the diet of fishes in a hydrologically variable northern Australian river. Journal of Fish Biology 77:731-753.

Pusey, B. J., and M. J. Kennard. 1996. Species richness and geographical variation in assemblage structure of the freshwater fish fauna of the wet tropics region of northern Queensland. Marine and Freshwater Research 47:563-573.

Pusey, B., M. Kennard, and A. Arthington. 2004. Freshwater fishes of north-eastern Australia. CSIRO publishing, Melbourne, Australia.

Pusey, B. J., M. G. Read, and A. H. Arthington. 1995. The feeding ecology of freshwater fishes in two rivers of the Australian Wet Tropics. Environmental Biology of Fishes 43:85-103. 
$\rightarrow$ Rayner, T. S., B. J. Pusey, and R. G. Pearson. 2009. Spatiotemporal dynamics of fish feeding in the lower Mulgrave River, north-eastern Queensland: the influence of seasonal flooding, instream productivity and invertebrate abundance. Marine and Freshwater Research 60:97-111.

Roach, K. A., M. Tobler, and K. O. Winemiller. 2011. Hydrogen sulphide, bacteria, and fish: a unique, subterranean food chain. Ecology 92:2056-2062.

Romanuk, T. N., L. J. Jackson, J. R. Post, E. McCauley, and N. D. Martinez. 2006. The structure of food webs along river networks. Ecography 29:3-10.

Sainty, G. R., and S. W. L. Jacobs. 1994. Waterplants in Australia. $3^{\text {rd }}$ edition. CSIRO Australia, Sainty and Associates, Sydney, Australia.

Sarbu, S. M., T. C. Kane, and B. K. Kinkle. 1996. A chemoautotrophically based cave ecosystem. Science 272:19531955.

Sheldon, F. 2005. Incorporating natural variability into the assessment of ecological health in Australian dryland rivers. Hydrobiologia 552:45-56.

Thorp, J. H., and M. D. Delong. 1994. The riverine productivity model: an heuristic view of carbon sources and organic processing in large river ecosystems. Oikos 70:305308.

Thorp, J. H., and M. D. Delong. 2002. Dominance of autochthonous autotrophic carbon in food webs of heterotrophic rivers. Oikos 96:543-550.

Thorp, J. H., M. C. Thoms, and M. D. Delong. 2006. The riverine ecosystem synthesis: biocomplexity in river networks across space and time. River Research and Applications 22: 123-147.

Vander Zanden, M. J., G. Cabana, and J. B. Rasmussen. 1997. Comparing the trophic position of freshwater fish calculated using stable nitrogen isotopes $\left(\delta^{15} \mathrm{~N}\right)$ and literature dietary data. Canadian Journal of Fisheries and Aquatic Sciences 54:1142-1158.

Vander Zanden, M. J., and J. B. Rasmussen. 1999. Primary consumer $\delta^{13} \mathrm{C}$ and $\delta^{15} \mathrm{~N}$ and the trophic position of aquatic consumers. Ecology 80:1395-1404.
Vannote, R. L., G. W. Minshall, K. W. Cummins, J. R. Sedell, and C. E. Cushing. 1980. The river continuum concept. Canadian Journal of Fisheries and Aquatic Sciences 37:130137.

Vermaat, J. E., J. A. Dunne, and A. J. Gilbert. 2009. Major dimensions in food-web structure properties. Ecology 90: 278-282.

Warfe, D. M., N. E. Pettit, R. H. Magierowski, B. J. Pusey, P. M. Davies, M. M. Douglas, and S. E. Bunn. 2013. Hydrological connectivity structures concordant plant and animal assemblages according to niche rather than dispersal processes. Freshwater Biology 58:292-305.

Watson, A., and L. A. Barmuta. 2011. Feeding-preference trials confirm unexpected stable isotope analysis results: freshwater macroinvertebrates do consume macrophytes. Marine and Freshwater Research 62:1248-1257.

Werner, E. E., and J. F. Gilliam. 1984. The ontogenetic niche and species interactions in size-structured populations. Annual Review of Ecology, Evolution, and Systematics 15: 393-425.

Winemiller, K. O. 2004. Floodplain river food webs: generalizations and implications for fisheries management. Pages 285-309 in R. Welcomme and T. Petr (editors). Proceedings of the $2^{\text {nd }}$ International Symposium on the Management of Large Rivers for Fisheries. Volume II. Food and Agricultural Organization of the United Nations and the Mekong River Commission, Phnom Penh, Cambodia.

Winemiller, K. O., S. Akin, and S. C. Zeug. 2007. Production sources and food web structure of a temperate tidal estuary: integration of dietary and stable isotope data. Marine Ecology Progress Series 343:63-76.

Winemiller, K. O., S. C. Zeug, C. R. Robertson, B. K. Winemiller, and R. L. Honeycutt. 2011. Food web structure of coastal streams in Costa Rica revealed by dietary and stable isotope analyses. Journal of Tropical Ecology 27:463476.

Zeug, S. C., and K. O. Winemiller. 2008. Evidence supporting the importance of terrestrial carbon in a large-river food web. Ecology 89:1733-1743. 